\title{
The Inconvenience of the Legislator's Two Persons and the Role of Good Counsellors
}

\author{
Gabriella Slomp* \\ School of International Relations, University of St Andrews, St Andrews, UK
}

I focus on Hobbes's distinction between the natural and political persons embodied in one sovereign and show that, driven by their passions, ignorance, or bad judgement, rulers qua natural men may undermine the end they ought to pursue qua political actors, namely the protection of the well-being of the people. In particular, as legislators, they may make laws that are unnecessary, or that the people cannot endure, or that give rise to their impatience and discontent. I argue that in Hobbes's argument, the notion of good counsel provides a safety net against bad commands being issued by rulers. I claim that the process of consultation of good counsellors is an essential component of Hobbes's understanding of law-making. I suggest that the Hobbesian notions of counsel and counsellor provide a valuable framework to illuminate aspects of contemporary global law-making.

Key words: sovereign, legislator, natural person, political person, command, counsel

\section{$\underline{\text { Introduction }}$}

In the Epistle Dedicatory of Leviathan, Hobbes famously states that his aim is to 'speak not of the men but (in abstract) of the Seat of Power' (Hobbes, 1991, p. 3). In spite of this commitment, however, in Leviathan and in his other political writings Hobbes speaks not just of the 'Seat' and of the abstract rights and duties that come with it, but also of the men occupying that seat, and of the multiplicity of problems that these men may create.

In this essay, then, I focus on the under-explored distinction between the political and the natural person that Hobbes attributes to sovereigns, be they monarchs or members of an assembly:

[E]very man, or assembly that hath Sovereignty, representeth two persons, or (as the more common phrase is) has two capacities, one Naturall, and another Politique, (as a Monarch, hath the person not onely of the Common-wealth, but also of a man; and a Sovereign Assembly hath the Person not onely of the Commonwealth, but also of the Assembly). (Hobbes, 1991, p. 166)

\footnotetext{
*Email: gs21@st-andrews.ac.uk
} 
This paper argues that there is a divergence between the theory and practice of sovereignty insofar as Hobbesian rulers qua natural men may undermine the end they ought to pursue qua political actors, namely the protection of the well-being of the people. In particular, as legislators, they may make laws that are unnecessary, or that the people cannot endure, or that give rise to their impatience and discontent. I contend that in Hobbes's theory the notion of good counsel provides a safety net against bad commands being issued by rulers. I claim that the process of consultation of good counsellors is an essential component of Hobbes's understanding of law-making. Finally, I suggest that the Hobbesian notions of counsel and counsellor provide a valuable framework to illuminate aspects of contemporary global law-making.

The paper is organized into sections: the first three sections provide a detailed textual analysis of Hobbes's argument on the legislator's two persons and the role of counsellors; the last section fleshes out the interpretation of Hobbes's legal theory that the preceding analysis supports, and draws some implications for contemporary debates.

\section{The Legislator as Persona Civitatis}

Hobbes argues that in the state of nature individuals disagree on 'what is to be called right, what good, what virtue, what much, what little, what meum and tuum, what a pound, what a quart, \&c' (Hobbes, 1889, p. 188). No individual is strong enough to impose his or her own rules and standards on all others, and for this reason there is no natural end to controversies and quarrels. For the sake of self-preservation, each individual renounces their right to decide what is right and what is wrong, and transfers this right to the 'sovereign', who in the commonwealth is the only legislator (Hobbes, 1991, p. 184). The civil laws become to 'all subjects the measures of their actions, whereby to determine, whether they be right or wrong, profitable or unprofitable, virtuous or vicious' (Hobbes, 1889, p. 188-9; see also Hobbes, 1991, p. 183). 
In Hobbes's theory, the introduction of positive law protects individuals from the disorder of the state of nature. For Hobbes, ill-conceived or seemingly unfair laws are nevertheless superior to no positive laws at all, as the existence of law entails the existence of a commonwealth or union, and this in turn protects against the dangers of the war of all against all that one finds in the state of nature. Hobbes likens civil laws to hedges that guide the potentially errant traveller:

For the use of lawes, (which are Rules Authorised) is not to bind the People from all Voluntary actions; but to direct and keep them in such a motion as not to hurt themselves by their own impetuous desires, rashnesse, or indiscretion; as Hedges are set, not to stop Travellers, but to keep them in the way. (Hobbes, 1991, pp. 239-40)

Civil laws are 'nothing other than commands of the holder of sovereign power in the commonwealth' (Hobbes, 1998, p. 79; see also Hobbes, 1889, p. 172; Hobbes, 1991, p. 183) and must be obeyed by citizens because they proceed from the will of the authorised legislator who 'commands (...) as a Politick, not a Naturall person' (Hobbes, 2010, 174). 1

The sovereign is the origin of justice and therefore 'no law can be unjust' (Hobbes, 1991, p. 239). Hobbes concedes that Christians must obey God, but points out that God stopped speaking directly to Man long ago; Hobbes devotes much attention to scriptural exegesis in order to demonstrate that God commands Man to obey the civil authorities. Thus, for Hobbes, it is seditious for citizens to challenge or resist the civil law even if their claims are born from religious thought. The law of nature which 'forbids the violation of agreements' by implication 'commands that all civil laws be observed' (Hobbes, 1998, p. 159). Hobbes emphasises that 'the obligation to observe [the civil] laws is older than the promulgation of the laws themselves, because contained in the actual formation of the commonwealth' (Hobbes, 1998, pp. 158-9; also, Hobbes, 1991, p. 183). For Hobbes, a freelyundertaken political obligation precedes the making of specific laws, and this significantly 
distances the Hobbesian understanding of law-as-command from that of Austin and legal positivists, who see the command itself as the origin of the obligation. 2

The commands of the Leviathan and the Word of God are alike insofar as they require obedience regardless of whether or not we agree with their content. The Leviathan's commands, however, differ from those of God in one important respect. For Hobbes, God is unknowable (Hobbes, 2010, p. 167) and 'has no ends' (Hobbes, 1991, p. 249). Therefore, we cannot understand, for example, why Adam and Eve were forbidden to eat from one tree in the Garden of Eden; Hobbes points out that 'without the command, the fruit of the tree has nothing in its nature by which its eating could be morally bad' (Hobbes, 1998, p. 188). In contrast, the Leviathan is a man-made god and hence we may understand its aim and functions as we understand the purpose and operations of a watch. We know that 'the end, for which [a Monarch or an Assembly] was trusted with the Sovereign power [is] the procuration of the safety of the people' (Hobbes, 1991, p. 231 emphasis in original), and that the sovereign is given absolute and unlimited power in order to attain this end. It follows that the ultimate purpose of all the civil laws introduced by the sovereign is to serve the salus populi.

Indeed, Hobbes tells us that 'a good Law is that, which is Needful, for the Good of the People' (Hobbes, 1991, p. 239, emphasis in original). Civil laws should pursue the well-being of the people in a very broad sense, and also make provisions for the protection of the most vulnerable:

And whereas many men, by accident unevitable, become unable to maintain themselves by their labour; they ought not to be left to the charity of private persons; but be provided for, (as far-forth as the necessities of nature require,) by the Lawes of the Common-wealth. For as it is Uncharitablenesse in any man, to neglect the impotent; so it is in the Sovereign of a Common-wealth, to expose them to the hazard of such uncertain Charity (Hobbes, 1991, p. 239).

According to Hobbes, rulers have every reason to issue good laws because to do so is in their own interest on this earth and in the interest of their salvation in the afterlife. To support the 
second half of this conjunction, Hobbes tells us that the laws of nature that recommend the conditions of society and peace among men (Hobbes, 1998, p. 21) are the eternal Law of God' (Hobbes, 1991, p. 192; p. 231), and that the sovereign is accountable to God (Hobbes, 1991, p. 231) if he does not endeavour to follow the laws of nature. Hobbes does not detail precisely how the natural laws should inspire the Leviathan in domestic and international politics; he leaves it to his readers to speculate. Whereas '[w]e cannot safely judge of men's intentions' (Hobbes, 2010, p. 200), Hobbes suggests that we can safely assume the intention of the legislator as political actor: 'the intention of the Legislator is always supposed to be Equity' (Hobbes, 1991, p. 194). Hobbes refers repeatedly to equity as 'the principall Law of nature' (Hobbes, 1991, p. 195) and the 'eternall Law of God' (Hobbes, 1991, p. 199); indeed, this law is particularly relevant to the sovereign in his role as sole legislator and arbitrator. In addition to equity, the laws of nature that recommend against cruelty, arrogance, revengefulness, greed and so forth should also presumably inspire the Leviathan's rulings. In all of Hobbes's works, the law of nature that recommends 'gratitude' occupies a high place on his list of natural laws; as argued by David Van Mill (2001, p 164), gratitude ought to inspire the sovereign's attitude towards the people. Indeed, as the sovereign is not part of the social contract but is given his position of power as a 'free gift', and Hobbesian individuals are said to give free gifts only 'upon hope to benefit from such action in the future' (Hobbes, 1998, p. 35), it follows that the sovereign ought 'to try to ensure that the giver [of the gift] not have reason to be sorry he gave it' (Hobbes, 1998, p. 47; also, Hobbes, 1991, p 105).

As mentioned above, it is not just for the sake of their eternal salvation that rulers should govern well, but also because it is in their earthly self-interest to do so. Throughout his works, Hobbes emphasises that 'the good of the Sovereign and People, cannot be separated' (Hobbes, 1991, p. 240). He takes issue with Aristotle's argument in the Politics that 'there are two sorts of governments, whereof the one relates to the benefit of the Ruler, the other to that 
of the Subjects' (Hobbes, 1998, p. 116; also, Hobbes, 1889, p. 138). For Hobbes, this notion is misguided as it fails to grasp the coincidence of interest of the sovereign and the people. 3 He insists that:

The benefit ...for which a body politic was instituted, namely, the peace and preservation of every particular man ... extendeth equally both to the sovereign and to the subjects. For he or they that have the sovereign power, have but the defence of their persons, by the assistance of the particulars; and every particular man hath his defence by the union in the sovereign. As for other benefits which pertain not to their safety and sufficiency, but to their well and delightful being, such as are superfluous riches, they so belong to the sovereign, as they must also be in the subject, and so to the subject, as they must also be in the sovereign. For the riches and treasure of the sovereign, is the dominion he hath over the riches of his subjects. (Hobbes, 1889, pp. 137-8; also, Hobbes, 1998, p. 116; Hobbes, 1991, p. 240)

To conclude, the Great Leviathan is created with the purpose of protecting the people, and undivided, absolute power is the means he is given to perform this function. Although not subject to the civil laws (Hobbes, 1991, p. 184), the legislator must serve the salus populi as suprema lex. As a watch that does not keep time is discarded, likewise a sovereign legislator that does not protect his people loses his raison d'être. Considerations of advantage on this earth, and of salvation in the after-life, ensure that the rational legislator will introduce laws that safeguard and advance the welfare of the commonwealth.

\section{The Legislator as Persona Naturalis}

Having argued that the sole aim of the sovereign's absolute and undivided power is to promote the wellbeing of the people, Hobbes recognises that most individuals are nonetheless frightened by the idea of being subject to such a formidable entity. Hobbes explains that individuals' 'aversion' for the notion of absolute sovereignty is 'partly the fault of those who misuse their authority for their own greed when they are appointed to such a position of power' $(1998$, p. 87). He acknowledges that people are afraid 'that the holder of the sovereign power may not only set penalty he pleases for any offence he wishes, but may also, from 
anger and greed, put innocent citizen to death who have done nothing against the laws' (Hobbes, 1998, p. 120; also, Hobbes, 2005, p. 38).

Although the ruler cannot act unjustly in their political capacity, Hobbes admits that rulers as natural men may fall short of what is expected of them in their political capacity; throughout his works we come across statements such as the following:

The sovereign (considered in his natural person, and not in the person of the commonwealth) can make mistakes and can even sin. (Hobbes, 1889, p. 138)

It is true that a sovereign monarch or the greater part of a sovereign assembly may ordain the doing of many things in pursuit of their passions contrary to their consciences which is a breach of trust and of the law of nature. (Hobbes, 1991, p. 172-3)

There are however many ways in which people, a council of optimates and a Monarch can sin against natural laws, by cruelty, for example, by unreasonableness, by insolence and by other vices, which do not come under the strict and accurate signification of wrong. (Hobbes, 1998, p. 97)

Hobbes emphasises that whenever rulers fail to deliver what they ought, 'the fault is the Ruler's, not the Regime's. Not all the deeds of Nero are of the essence of Monarchy' (Hobbes, 1998, p. 120). Occasionally Hobbes refers to rulers with good qualities: James I is praised for his wisdom, Charles I for his virtues of body or mind, Henry VIII for his severity, Henry VII for filling his coffers, and so forth. More often, however, Hobbes conveys the idea that historical rulers are passionate men that rarely possess all the qualities that are needed. Indeed, in Behemoth one of the speakers comments that when the virtues of Henry VII and Henry VIII 'shall be jointly in one King' the commonwealth will be cured (Hobbes, 2010, p. 181).

In Hobbes's texts we encounter two main explanations for bad government. First, as natural people, rulers are as subject to the disorder of the passions as other men. In his dedicatory letter of the Leviathan, Hobbes urges those who are 'to govern a whole nation' to look inside themselves: introspection will enable them to understand mankind (Hobbes, 1991, 
p. 11). Across his works, Hobbes attributes to rulers the gamut of human emotions, from desire of power 4 to 'greed' (Hobbes, 1998, p. 87), from 'iealousie' to fear (Hobbes, 2010, p. 141), from anger and cruelty (Hobbes, 1998, p. 97) to 'negligence' and hazardousness (Hobbes, 1991, p. 173), from vain glory to 'timorousness' (Hobbes, 1991, p. 220). This happens not just when the sovereign is an assembly, but also in Hobbes's preferred form of government: 'affections and passions ... reign in everyone, as well monarch as subject; by which the monarch may be swayed to use [his] power amiss' (Hobbes, 1889, p. 141). Hobbes adds that 'the monarch besides the riches necessary for defence of the commonwealth may take so much from the subjects as may enrich his children, kindred and favourites to what degree he pleaseth' (Hobbes, 1889, p. 142).

The second explanation for defective ruling one can encounter in Hobbes's texts, is rulers' flawed reasoning and ignorance. For example, Hobbes points out the bad judgement of those rulers who grant special treatment to those subjects of whom they are afraid:

The benefits which a Sovereign bestoweth on a Subject, for fear of some power, and ability he hath to do hurt to the Common-wealth ... are Sacrifices, which the sovereign (considered in his natural person, and not in the person of the commonwealth) makes for the appeasing the discontent of him he thinks more potent than himself; and encourage not to obedience, but on the contrary to the continuance, and increasing of further extortion. (Hobbes, 1991, p. 220 emphasis added; see also p. 241)

Hobbes is consistently clear that if rulers reasoned well, and were not ignorant of the rights and duties of sovereignty, they would pursue the common interest because it is inseparable from their own. He offers many examples of rulers' misguided judgement; for instance he mentions kings who 'deny themselves some such necessary power not always (though sometimes) out of ignorance of what is necessary to the office they undertake; but many times out of a hope to recover the same again at their pleasure: wherein they reason not well' (Hobbes, 1991, p. 222, emphasis added). He also discusses kings who, in their natural 
capacity, promise to act in a manner that is incompatible with their political role, thereby showing their ignorance of the rights and duties of sovereignty (Hobbes, 1998, p.100). In Hobbes's account 'ignorance of the Rights of sovereignty' seems to affect rulers of commonwealth by institution and rulers of commonwealth by acquisition alike (Hobbes, 1991, p. 142)

Bad judgement can lead rulers to appoint, or fail to punish, corrupt officials that are in charge of the administration of the commonwealth. And bad administration is a major source of discontent among the people, and has far-reaching consequences for the stability and peace of the state.

Arguably, Hobbes draws a distinction between the shortcomings of monarchs on the one hand, and the inadequacies of assemblies on the other. In spite of being equally exposed to the disorder of the passions and to faulty judgement, monarchs are said to differ from members of assemblies insofar as it is easier for them to appreciate that their self-interest is inseparable from that of the commonwealth (Hobbes, 1991, p. 131). We may infer that Hobbesian monarchs are bad rulers when they fail to understand how to serve the common interest, which they know to coincide with their own. In contrast, assemblies rule poorly when their members are unable to realise what their self-interest truly is, and pursue instead an apparent good that damages the commonwealth and thus ultimately them themselves. The characteristic inability of members of a ruling assembly to see that their interest coincides with the interest of the commonwealth provides the foundations for Hobbes's argument against democracy as form of government.

On the consequences of bad ruling Hobbes expresses views that are prima facie contradictory. On the one hand, Hobbes plays down the problems created by sovereigns qua natural men, calling them 'inconveniences'. He reminds citizens that life is never without inconveniences, that nothing is absolutely good or evil, that human nature is what it is, that 
bad government is better than no government, that monarchies are preferable to aristocracies and democracies because '[i]n a monarchy ... anyone who is prepared to live quietly is free from danger, whatever the character of the ruler' (Hobbes, 1998, p. 120). He reassures citizens that 'no example readily comes to mind of a subject robbed of life and property by his prince from sheer caprice without any fault on his part' (Hobbes, 1998, p. 126).

On the other hand, Hobbes puts across a different message, namely that bad government causes discontent, that discontent is the ultimate source of rebellion, and that no ruler can ignore 'the danger that may arrive to himselfe in his natural Person, from rebellion' (Hobbes, 1991, p. 233). In the Dialogue we learn that dissatisfaction with the King's behaviour, and in particular his favouritism, was a major factor contributing to civil war: '[t]he greatest Complaint by them made against the unthriftiness of their Kings was for the inriching now and then a favourite' (Hobbes, 2005, p. 15; see also Hobbes, 1998, p. 119 and Hobbes, 1889, p. 142).

Hobbes's apparent contradiction, however, dissolves if we assume that his theory contains two strands of argument, one aimed at rulers, and one at the ruled 5: to the ruled Hobbes recommends endurance, and to the rulers he commends self-restraint.

To summarise, in Hobbes's argument we notice a discrepancy between the theory and practice of sovereignty; while in principle rulers have every reason to protect the ruled, in reality, blinded by their passions, misguided by ignorance, and misled by poor judgement, rulers may damage the commonwealth. While in principle (as shown in the former section) the positive law is neither contrary to the laws of nature, nor detrimental to the well-being of the commonwealth, in practice it may turn out to be all those things. The distinction made by Aristotle between bad rulers pursuing their private interest on the one hand, and good rulers pursuing the public interest on the other hand, becomes to Hobbes a distinction between enlightened rulers capable of pursuing their 'true self-interest', which coincides with the 
interest of the people, versus misguided rulers who fail to understand how to pursue their selfinterest, or what their self-interest truly is.

In addition, in Hobbes's texts we have found two explanations for bad ruling: one is passions-based, and the other is reason-based. 6 Although there is ample scope for debate, it may be argued that in Hobbes's theory the rulers' passions do not provide a sufficient condition for misrule: greed alone, or glory alone - without a mistaken opinion about the long-term consequences of greed- or glory-seeking behaviour - cannot induce Hobbesian kings to abuse their power. By contrast, according to our analysis, poor judgement is not only a necessary but also a sufficient condition for bad government: out of ignorance moderate rulers may do things that damage the commonwealth.

This interpretation of bad ruling provides Hobbes with the belief that misrule can in principle be cured. Indeed if misgovernment was the inevitable outcome of rulers' passions, there would be no solution to the problem because the passions cannot be removed from the heart of Hobbesian men. However, in so far as poor judgement plays a pivotal role in bad government, and judgement can be educated and assisted, Hobbes is able to offer a solution to bad ruling by providing rulers with the aid of good counsellors. The burden of the next section is to support this latter claim.

The Legislator and their Counsellors

Following Hobbes we compared the Leviathan to a watch and noted that the purpose and function of both can be fully understood as they are both designed by man. There is, however, a crucial difference between the Leviathan and a watch: whereas the latter is predictable, its mechanism regular, its movement exact, the former can be erratic and inconstant; this is because the sovereign is embodied in a natural person, and the passions and actions of a natural person cannot be predicted nor controlled. In the abstract, a rational legislator will only issue commands that are conducive to the well-being of the 
commonwealth, however in practice law-makers fail to achieve this ideal. Hobbes alerts his readers to this divergence between theory and practice:

In the Distribution of land, the Common-wealth it selfe, may be conceived to have a portion, and possesse, improve the same by their Representatative; and that such portion may be made sufficient, to susteine the whole expence to the common Peace, and defence necessarily required: Which were very true, if there could be any representative conceived free from human passions and infirmities. But the nature of men being as it is, the setting forth of Publique Land, or of any certaine revenue for the Common-wealth, is in vaine. (Hobbes, 1991, pp. 172-3, emphasis added)

But then, if actual rulers inevitably fall short of being enlightened legislators, how can the well-being of the commonwealth be protected? The aim of this section is to argue that Hobbes answers this question using the under-studied notion of 'counsel'. 7

We may begin by recalling that in the Dialogue the Lawyer states that to lay down the laws of the Saxons, "the Kings called together the Bishops, and a great part of the wisest and discreetest men of the Realm, and made Laws by their advice', on which procedure the Philosopher comments:

[T] here is no King in the World, being of ripe years and sound mind, that made any Laws otherwise; for it concerns them in their interest to make such Laws as the people can endure, and may keep them without impatience, and live in strength and courage to defend their King and Countrey, against his potent neighbours. (Hobbes, 2005, p. 144)

Assuming that the Philosopher voices Hobbes's opinion, we are told that the king 'of sound mind' seeks counsel in order to issue laws that can be endured by the people and secure their contentment and fidelity. Hobbes is clear that 'absolute Kings have their counsellors, by whom they wish to be advised and to have their commands in all important matters reviewed, though not revoked' (Hobbes, 1998, p. 83).

Hobbes's account of the civil war in Behemoth, where references to good and evil counsel and counsellors are constant and telling, suggests the topical relevance of 'counselling' in seventeenth century England: we are told that the Scots were claiming that 
the King was 'in the hands of euill Counsellors' (Hobbes, 2010, p. 148), that little by little the Parliamentarians removed 'from about [the King] those they thought could best councell him', that one of the Parliament's plots was 'to make the King giue vp his friends and Councellors to them to be put to death, banishment, or imprisonment, for their good will to him' (Hobbes, 2010, p. 212), and so forth.

In this paper, we shall focus mainly on Chapter XXV of Leviathan ('Of Counsell') the chapter that, perhaps revealingly, immediately precedes 'Of Civill Lawes' - to examine the part played by counsellors in preventing or mitigating problems that may come to the commonwealth as a consequence of the passions, ignorance, or poor judgement of rulers. For this purpose it is worth reminding ourselves of the role, disposition of mind, intellectual abilities, expertise, and status that Hobbes ascribes to good counsellors to the sovereign, and then we will inspect the process of consultation that, according to Hobbes, facilitates good counsel.

The role of counsellors is, unsurprisingly, to provide 'counsel'. Hobbes defines counsel as advice that is given in the interest of the counselled and not of the counsellor:

Therefore between Counsel and Command, one great difference is, that Command is directed to a man's own benefit; and Counsel to the benefit of another man. (Hobbes, 1991, p. 176)

Such a definition sheds light on the disposition of mind required in a counsellor: he must be capable of considering the good of someone else and possess the good will to advise him on how to attain it:

A counsellor ... (by the definition of Counsell) ought to regard, not his own benefit, but his whom he adviseth. (Hobbes, 1991, p. 178)

As such an attitude of mind is at odd with his description of human psychology, Hobbes remarks that "they that give Counsell to the Representative person of a Common-wealth, may have, and have often their particular ends, and passions, that render their Counsells always suspected, and many times unfaithful' (Hobbes, 1991, p. 179), and sets down 'for the first 
condition of a good Counsellour, That his Ends and Interest, be not inconsistent with the Ends and Interest of him he Counselleth' (Hobbes, 1991, p. 179, emphasis in original). Hobbes stresses that 'he that giveth counsel to his Soveraign, (whether a Monarch, or an Assembly) when he asketh it, cannot in equity be punished for it' (Hobbes, 1991, p. 177, emphasis added), thereby suggesting that a good counsellor acts in good faith.

With regard to counsellors' disposition of mind, Hobbes distinguishes between 'corrupt Counsellours' who are 'bribed by their own interest' (Hobbes, 1991, p. 178) and resort to exhortations and dehortations when they deliver counsel, and good counsellors who are able to consider and advise in the interest of the counselled and to offer advice 'as briefly as the evidence will permit' (Hobbes, 1991, p. 179-80) using 'firm ratiocination' and using 'significant and proper language (Hobbes, 1991, p. 179) 8.

In addition to the above attitude of mind, a good counsellor needs specific intellectual abilities. While in On the Citizen Hobbes likens counsellors to the 'head' of the commonwealth 9, in Leviathan, Hobbes attributes to counsellors specific faculties of mind, namely 'memory' and 'mentall discourse':

Counsellors, by whom all things needful for [the Artificial Man] to know, are suggested unto it, are the memory. (Hobbes, 1991, p. 9)

And to the Person of the Commonwealth, his Counsellors serve him in the place of Memory and Mentall Discourse. (Hobbes, 1991, p. 179)

The counsellors' memory of relevant political experiences, combined with rationality, provides solid ground for prudent and wise counsel:

he who hath by Experience, or Reason, the greatest and surest prospect of consequences Deliberates best himselfe; and is able when he will, to give the best counsell unto others. (Hobbes, 1991, p.46)

Experience, memory, and reason enable counsellors to have good judgement, and judgement is the 'wit required for Counsel' (Hobbes, 1991, p. 180). Thus Hobbes sees sound counsel as a corollary of rational intellectual ability; Hobbes distinguishes 'apt' and 'fit' counsellors 
from 'inept' and 'unfit' counsellors and points out that 'the Vertues, and Defects of Counsell, are the same with the Vertues, and Defect Intellectuall' (Hobbes, 1991, p. 179).

In addition to intellect, Hobbes believes that a wide range of practical knowledge and expertise is required to advise a commonwealth (Hobbes, 1991, p 180). Hobbes points out that very few people have the relevant expertise and that members of assemblies usually lack it.

Lastly, Hobbes highlights the status of a counsellor and explains that 'Counsellors without other employment then to advise are not public ministers'; he expands:

Neither a counsellor nor a councell of state if we consider it with no authority of Judicature or command but only of giving advice to the sovereign when it is required, or of offering it when it is not required is a Public person. For the Advice is addressed to the Sovereign only, whose person cannot in his own presence be represented to him by another. (Hobbes, 1991, p. 170)

In Hobbes's argument, all the above characteristics (disposition of mind, intellectual abilities, expertise, and status) do not guarantee good counsel. Hobbes emphasises the importance of the process by which consultation is sought or offered. He is adamant that public consultation and debate ignites the natural ambition that is latent in many people, and spurs them to have their own counsel adopted, and to use rhetoric rather than logic to win the argument. Hence, Hobbes arrives at the view that public consultation in assemblies rarely produces good counsel.

Indeed, Hobbes suggests that public consultations are not merely structurally prone to poor judgements, but are intrinsically deleterious to the security of the commonwealth. For Hobbes, public debate allows the rulers' enemies (both domestic and foreign) to be privy to the same information as the rulers' friends. Therefore, Hobbes suggests that while private consultation with selected counsellors improves a ruler's deliberative process and is beneficial to the commonwealth, public consultations can be worse for the commonwealth than the rulers' unchallenged reliance on his own judgement: 
A man that doth his businesse by the help of many and prudent Counsellours, with everyone consulting apart, does it best, as he that useth able Seconds at Tennis play, placed in their proper stations. He does next best, that useth his own Judgement only; as he that has no Second at all. But he that is carried up and down to his businesse in a framed which cannot move but by the plurality of consenting opinions ...does it worst of all. (Hobbes, 1991, p. 183)

Finally, we may recall from the previous section that Hobbes gives examples of decisions by rulers that show their ignorance of the rights and duties of sovereignty. Hobbes regarded such rights and duties as part of the 'infallible rules' of politics that he had himself demonstrated in On the Citizen 10; in the chapter on Counsel in Leviathan, on such abstract matters, the understanding of which require the use of the correct method and devoted periods of study, Hobbes appears to be offering to the sovereign his own counsel. He writes:

when for the doing of anything, there be Infallible rules (as in Engines, and edifices, the rules of Geometry) all the experience of the world cannot equall his Counsell, that has learned, or found out the Rule. (Hobbes, 1991, p. 180)

To conclude, we had established in the foregoing sections that Hobbes saw a problem in the embodiment of the sovereign in a natural man: because of their emotions, their fallible thought processes, their ignorance, the sovereign may not act as they ought in their political capacity. According to our reading of texts, Hobbes sees careful consultation with appropriate counsellors as a practical solution to this problem.

\section{Command, Counsel, and Law-Making: an Overview}

Based on the textual analysis of the foregoing sections, we can now advance an interpretation of Hobbesian law-as-command, and of the role of counsel in law-making. As a preliminary, it may be helpful to summarise the main findings thus far.

First, we argued that disagreements on values (on right and wrong, just and unjust, and so on) turn the state of nature into a state of war, and motivate Hobbesian men to authorise a sovereign legislator (which may be a monarch or an assembly) to arbitrate upon the 'rules' and 'measures' of their actions. Thus a 'decision' is at the foundation of Hobbes's understanding of civil law. In abstracto, the arbitrariness of the sovereign's decision is 
limited by some important constraints described by Hobbes: the sovereign legislator ought to issue only commands that serve the purpose for which the commonwealth was created, namely the salus populi, and ought to capture the spirit of the laws of nature in the legislation. In abstracto, furthermore, the sovereign's self-interest will drive him to perform his duty, as his own wellbeing (security and wealth on this earth, and salvation in the afterlife) depends on the wellbeing of the people.

Second, we showed that in practice, rulers may be swayed by passions, misled by ignorance, or misguided by poor judgement and therefore they may fail comprehend how to attain the salus populi, or they may mistake an apparent good for their true self-interest. Due to this theory-practice gap, wrong-headed rulings and deficient legislation can be made in practice. We noted that Hobbes refers to the problems caused by real rulers as 'inconveniences' and we distinguished two separate strands within his argument: one, directed at citizens, reminds them that the very existence of law, regardless of its content, provides a state of peace, and peace entails as a minimum 'lack of war'. Another argument, presumably directed at rulers themselves, suggests that only good laws ensure the people's obedience and create the conditions for lasting peace.

Third, we claimed that in order to minimise the distance between the theory and the practice of sovereignty, Hobbes uses the notion of 'counsel'. With their sound judgement, memory, experience, and expertise, 'good counsellors' can assist the sovereign in the deliberations that precede the issuing of commands. We suggested that the concept of 'counsel' is for Hobbes an integral part of the practical process of law-making, and that it is no coincidence that the chapter on Counsel in Leviathan immediately precedes the Chapter on Civil Laws.

According to our reading of texts (i) the very existence of positive law is a protection against the disorder of the state of nature; (ii) the law is not the source of political obligation 
but its consequence; (iii) regardless of content, any law issued by the authorised law-giver is binding; (iv) a law is 'good' if it is 'necessary' for the salus populi; (v) a law is 'good' if it captures the spirit of the laws of nature which recommend the conditions of peace and advise against inequity, revengefulness, cruelty, pride, partiality, greed, and so forth; (vi) in practice a law is more likely to be good if it is issued after careful consultation with experienced and wise counsellors.

To put the same thing in different words, in Hobbes's argument we have found the function of law (i); the formal requirements of a valid law [(ii), (iii)]; some guidance to evaluate whether the substance of law is 'good' [(iv), (v)], and an indication of the procedure that can facilitate the issuing of good laws (vi) $\mathbf{1 1}$.

On the one hand, some arbitrariness is built into Hobbes's concept of law (Letwin 2005); the ambiguity of conditions (iv), (v), and (vi) is evident when we remind ourselves that, although some behaviours such as cruelty and vengefulness are (and will always be) condemned by the laws of nature, for Hobbes there is no objective way of establishing which acts count as cruel: 'one man calls cruelty what another calls justice' (Hobbes, 1991, p. 31). Indeed, Hobbes maintains that one cannot conclusively establish the 'obscure' laws of nature at all:

The unwritten law of nature, though it be easy to such as without partiality and passion make use of their natural reason, and therefore leaves the violators thereof without excuse; yet considering there be very few, perhaps none, that in some cases are not blinded by self-love, or some other passion, it is now become of all laws the most obscure, and has consequently the greatest need of able interpreters. (Hobbes, 1991, p. 190-1)

In his writings, Hobbes often highlights the role of the sovereign decision in interpreting the laws of nature:

Theft, murder, Adultery, and all injuries are forbid by the Lawes of nature; but what is to be called Theft, what murder, what Adultery, what injury in a Citizen, this is not to be determined by the naturall, but by the civill Law: for not every taking away of the thing which another possesseth, but onely another mans goods is theft; but what is ours, and what anothers, is a question belonging to the civill Law. In like manner, not 
every killing of a man is murder, but onely that which the civill Law forbids; neither is all encounter with women Adultery, but onely that which the civill Law prohibits. (Hobbes, 1998, p. 16)

On the other hand, in spite of his nominalism, Hobbes suggests that the meaning of the salus populi is largely uncontroversial, and that a rational legislator with his counsellors can establish how to secure it in practice.

Where does this leave us? In the history of the concept of law, Hobbes's legal theory is generally seen as a move away from ancient and medieval theories of law: Hobbes's laws are not linked to any sort of cosmic order, nor anchored to eternal truths, and thus mark the beginning of a genuinely new phase in legal thinking 12. In this paper we have seen that the salus populi is the anchor of Hobbesian jurisprudence and sets limits to arbitrariness: 'a good Law is that, which is Needful, for the Good of the People' (Hobbes, 1991, p. 239, emphasis in original). By focusing on the Hobbesian distinction between the natural and political persons embodied in rulers, and by examining the role of counsel and command in law-making, this paper has shown that - in addition to a definition of 'valid' and formally 'good' law - Hobbes's legal theory contains a discussion of both the substance of good laws and the practice of law-making. According to our reading, counselling is an important component of Hobbes's discourse on law and sheds light on his conviction that for the sake of the peace of real commonwealths the practice of law-making is all-important. Counsellors, Hobbes stresses, are both the 'memory' and 'mental discourse' of the Great Leviathan: Hobbesian law-making is an activity that takes into account relevant past experience as well as the changing needs of the commonwealth.

Admittedly, on counselling, Hobbes makes a number of claims that do not resonate with the contemporary reader. First, we have argued that throughout his writings Hobbes voices his disapproval of consultative bodies or assemblies, and recommends the exclusive use of private counsellors 13; indeed, because of his understanding of human psychology, 
Hobbes believed that public debate prevents the delivery of good counsel. Second, Hobbes stresses that no counsellor can claim a 'right' to provide counsel, nor to have their counsel followed by the legislator because such rights would effectively divide the sovereign power.

This notwithstanding, some of Hobbes's reflections on command and counsel may offer a valuable framework to illuminate different aspects of global law-making today $\mathbf{1 4}$.

On one level, we can use Hobbes's concepts of command and counsel to shed light on the relationship between states-as-legislators on the one hand and NGO's-as-counsellors on the other, and to distinguish between different types of NGOs counselling. Although Hobbesian states would not accept internal or external challenges to their sovereignty, arguably they would be willing to follow practical impartial advice aimed at increasing domestic and international stability and peace. While Hobbesian Leviathans would resist or ignore self-appointed counsellors that publicly critique their policies or dispute their sovereign rights, they should be willing to engage with counsellors who take a neutral and objective standpoint and propose practical ways to address existing problems and concerns. The question arises of to what extent NGOs can meet all the criteria of the Hobbesian counsellor, and in particular the criterion that good counselling is always in the interest of the counselled. From the Hobbesian perspective on counselling, one needs to re-visit the notion of the interests that states are supposed to represent and to reflect on the relationship between the interest of governments and people.

On another level, the role of counsel in modern day international law might be seen in the way that organizations such as the International Committee of the Red Cross play a crucial part in providing information and advice on international law-making, demonstrating how Hobbes's insights into counselling can offer a normative justification for practices that challenge the sovereign role of states in the international legal realm. Interestingly, the 
ICRC's mission statement contains a number of pledges that can be interpreted through the Hobbesian lens of counselling: a promise of neutrality and impartiality, a commitment to discretion and to refrain from publicity, and above all the undertaking of counselling in the interest of humanity. $\mathbf{1 5}$.

To conclude, although Hobbes puts forward an argument on counselling that is in many ways contextual and therefore interesting only from a historical point of view, he also offers a perspective that enables us to rethink critically the different meaning, role and significance of NGOs and INGO's in global law-making today. 


\section{Acknowledgements}

I would like to thank Maximilian Jaede, John Horton, and Camillo Lamanna for their insightful comments. I am also grateful to Glen Newey for very constructive criticisms and helpful suggestions. Last but not least I wish to thank Tony Lang for helping me with the final part of the paper.

Notes

1- It is outside the scope of this paper to discuss civic disobedience. The topic is controversial; for my own understanding, see Slomp (2009)

2- On this see Claire Finkelstein (2005, p XIII )

3- For Hobbes the distinction between tyrant and king does not describe different forms or conditions of government but different feelings towards rulers and regimes (1998, p 93): a beloved ruler is called king, while one who is hatred is called a tyrant (1998, 116).

4- 'I put for a generall inclination of all mankind, a perpetuall and restlesse desire of Power after power, that ceaseth onely in Death. (...) And from hence it is, that Kings, whose power is greatest, turn their endeavours to the assuring it at home by Lawes, or abroad by Wars' (Hobbes 1991, 70).

5- As I argued elsewhere, I take the view that a number of contradictory remarks in Hobbes's texts (for example the claim that favouring friends is harmless and part of the King's prerogative, or dangerous and potentially part of his downfall) can be explained if we assume that in his writing he was addressing different audiences, the citizens and the King (Slomp 2015).

6- I owe this way of putting the point to Glen Newey. See also Newey 2008

7- Among the relatively few interpreters who have shown an interest in Hobbes's concepts of counsel and counsellor it is worth mentioning Susan Moller Okin 1982 and Adrian Blau 2009. At the time of writing the paper I was unaware of some recent very important work on counsel and command by Joanne Paul (2015).

8- For a stimulating discussion of corrupt counsellors, see Adrian Blau 2009

9- 'Almost everyone who makes the comparison of commonwealth and citizens with the body and its members says that the holder of sovereign power in the commonwealth is to the whole commonwealth what the head is to the whole man. But it appears from what has been said that the recipient of such power (whether man or council) has the relation to the commonwealth not of the head but of the soul (...) The appropriate analogy for the head is rather the corps of counsellors or (if he consults only one man) the single counsellor whose advice the holder of the sovereign power makes use of in the most important matters of government.' (Hobbes, 1998, p. 88-9)

10- 'The Rules of Just and Vniust sufficiently demonstrated, and from Principles euident to the meanest capacity, haue not been wanting; and notwithstanding the obscurity of their Author, haue shined not onely in this, but also in forraigne Countries to men of good education' (Hobbes, 2010, pp158-9 italics in the original).

11- I owe this way of putting the point to Maximilain Jaede. There are of course other aspects of Hobbes's law that this paper has not examined, such as the 'material circumstances' of a valid law, and the issue of punishment. Regarding punishment, we have seen that the protection/obedience principle is the foundation of the Hobbesian system of law; the sovereign's duty to protect entails the duty to punish those who disobey the law. Regarding the "material circumstances " of a valid law, 
Hobbes singles out promulgation or 'Declaration of the Law', 'sufficient signs of the Author' of the law (Hobbes 1991, 189) and intention or 'intendment' of the law: "The Legislator known, and the laws, either by writing, or by the light of nature, sufficiently published; there wanteth yet another very material circumstance to make them obligatory. For it is not the Letter, but the Intentment, or Meaning; that is the autentique interpretation of the Law" ( Hobbes, 1991, 190). For a recent stimulating discussion of what Hobbes calls the 'material circumstances' of a valid law, see May (2013).

12- Some interpreters see in Hobbes's legal theory an anticipation of Austin and legal positivism ('The traditional view of Hobbes on law holds that he is a legal positivist' (Finkelstein, 2005, p xiii)) while others see it as a precursor of Lon Fuller ('In my view, Hobbes's discussion of the natural law limits on positive law is similar to Lon Fuller's view in the Morality of Law' (May, 2013, p 121)

13- Contra Susan Moller Okin (1982)

14- I owe to Tony Lang the good points of this brief discussion of counselling in the contemporary world. All errors are my own.

15- In addition, on its official website, the ICRC gives details of its experience and expertise and of its long-standing history of good will and trustworthiness. As we have seen above, these are also characteristics that Hobbes attributes to good counsellors.

\section{$\underline{\text { Note on Contributor }}$}

Gabriella Slomp is reader at the University of St Andrews. She is the author of Thomas Hobbes and the Political Philosophy of Glory (Macmillan 2002) and editor by invitation of Thomas Hobbes (Ashgate 2008). She is a contributor to the Cambridge Companion to Hobbes's Leviathan (2008) and has published articles on Hobbes in Political Studies, History of Political Thought, Journal of Moral Philosophy and Telos. She is Associate Editor of Hobbes Studies.

\section{$\underline{\text { References }}$}

Blau, A., 2009 ' Hobbes on Corruption’ History of Political Thought vol 30 no 4 pp596-616

Finkelstein, C., 2005 Hobbes on Law. Farnham: Ashgate

Hobbes, 1889. The Elements of Law Natural and Politic. Ed. F. Toennies. London: Simpkin, Marshall, and Co.

Hobbes, T. 1991. Leviathan. Ed: R.Tuck Cambridge: Cambridge University Press

Hobbes, T., 1998. On the citizen. Ed. and trans. R. Tuck and M. Silverthorne. Cambridge: Cambridge University Press.

Hobbes, T., 2005. Writings on common law and hereditary right. Ed. A. Cromartie and Q. Skinner. Oxford: Clarendon Press.

Hobbes, T., 2010. Behemoth or the Long Parliament. Ed Paul Seaward. Oxford: Clarendon Press 
Jaede, M. (2015) 'Nature and Artifice in Hobbes's International Political Thought' Hobbes Studies Vol 23:1 pp18-34

Lang, A. 2015. International Political Theory: An Introduction. London: Palgrave.

Letwin, S. 2005 On the History of the Idea of Law Ed Noel Reynolds. Cambridge: Cambridge University Press

May, L., 2013. Limiting Leviathan: Hobbes on Law and International Affairs Oxford: Oxford University Press

Newey, G. 2008 Hobbes and Leviathan Abingdon and New York: Routledge

Okin, Susan Moller 1982. ""The Soveraign and His Counsellours": Hobbes's Reevaluation of Parliament', Political Theory Vol 10 No 1 pp 49-75.

Paul, J. 2015 ‘Counsel, Command, and Crisis’ Hobbes Studies Vol 28:2 pp

Slomp, G., 2009. 'Thomas Hobbes, Carl Schmitt, and the Event of Conscription', Telos 147 pp149-65

Slomp, G. 2015 'Limiting Leviathan: An Advice Book for Rulers? Larry May on Thomas Hobbes' Social Theory and Practice vol 41 no 1 pp 149-163

Van Mill, D., 2001. Liberty, Rationality, and Agency in Hobbes's Leviathan. New York: State University of New York Press. 